\title{
Clinical course and risk factors for recurrence of positive SARS-CoV-2 RNA: a retrospective cohort study from Wuhan, China
}

\author{
Jie Chen ${ }^{1,2, *}$, Xiaoping $X u^{1, *}$, Jing $\mathrm{Hu}^{1,2,{ }^{*}}$, Qiangda Chen ${ }^{3, *}$, Fengfeng $X \mathbf{u}^{1,2}$, Hui Liang ${ }^{1}$, Nanmei \\ $\mathrm{Liu}^{1,2}$, Hengmei Zhu ${ }^{2,4}$, Jinlong Lan ${ }^{1}$, Lan Zhou ${ }^{1,2}$, Jiajun Xing ${ }^{1}$, Ning $\mathrm{Pu}^{3}$, Zhigang Cai, \\ ${ }^{1}$ Department of Cardiothoracic Surgery, Naval Medical Center of PLA, Shanghai 200052, People's Republic of China \\ ${ }^{2}$ Department of Infectious Disease, Guanggu Branch of Hubei Province Maternity and Childcare Hospital, Hubei \\ 430073, People's Republic of China \\ ${ }^{3}$ Department of General Surgery, Zhongshan Hospital, Fudan University, Shanghai 200032, People's Republic of \\ China \\ ${ }^{4}$ Department of Special Treatment, Eastern Hepatobiliary Surgery Hospital, Naval Military Medical University, \\ Shanghai 200438, People's Republic of China \\ *Equal contribution and Co-first authors
}

Correspondence to: Zhigang Cai, Ning Pu; email: caizg12345@aliyun.com, https://orcid.org/0000-0002-3558-9391, npu15@fudan.edu.cn

Keywords: coronavirus disease 2019, COVID-19, SARS-CoV-2, recurrence, clinical course, risk factor

Received: June 2, $2020 \quad$ Accepted: July 14, 2020

Published: September 10, 2020

Copyright: Chen et al. This is an open-access article distributed under the terms of the Creative Commons Attribution License (CC BY 3.0), which permits unrestricted use, distribution, and reproduction in any medium, provided the original author and source are credited.

\section{ABSTRACT}

The coronavirus disease 2019 (COVID-19) pandemic is caused by the severe acute respiratory syndrome coronavirus 2 (SARS-CoV-2). The objective of this study was to determine the clinical course and risk factors for patients showing recurrent SARS-CoV-2 RNA positivity. A total of 1087 COVID-19 patients confirmed by RT-PCR from February 24, 2020 to March 31, 2020 were retrospectively enrolled. Advanced age was significantly associated with mortality. In addition, 81 (7.6\%) of the discharged patients tested positive for SARS-CoV-2 RNA during the isolation period. For patients with recurrent RT-PCR positivity, the median duration from illness onset to recurrence was $\mathbf{5 0}$ days. Multivariate regression analysis identified elevated serum IL-6, increased lymphocyte counts and CT imaging features of lung consolidation during hospitalization as the independent risk factors of recurrence. We hypothesized that the balance between immune response and virus toxicity may be the underlying mechanism of this phenomenon. For patients with a high risk of recurrence, a prolonged observation and additional preventative measures should be implemented for at least 50 days after illness onset to prevent future outbreaks.

\section{INTRODUCTION}

The coronavirus disease 2019 (COVID-19) pandemic is caused by the severe acute respiratory syndrome coronavirus 2 (SARS-CoV-2) [1, 2]. As of April 18, 2020, 2,121,675 confirmed cases of COVID-19 and 142,299 related deaths have been reported from 213 countries according to the World Health Organization (WHO) [3]. Although several studies have summarized the epidemiological and clinical features of SARS-CoV-
2 infection [4-6], and research is going on viral pathogenicity and mechanism. However, the exact origin of SARS-CoV-2 is controversial and a potential threat to a new outbreak $[7,8]$. Furthermore, little is known regarding the immune response against SARSCoV-2 infection, which in turn makes it difficult to assess complete recovery with no further risk of infection. The latter is a crucial factor in "flattening the curve" of COVID-19 and preventing additional outbreaks. 
In the early stages of the COVID-19 outbreak that was located to Wuhan, China, the severe shortage and limitations in the detection and accuracy of the RT-PCR test restricted identification of infected patients. The diagnostic techniques have improved substantially since [9], and two or more multipoint throat-swabs are taken over 24 hours apart prior to discharge in order to minimize the false negative rate of RT-PCR tests [10]. Lan L et al. [11] reported that four medical professionals with COVID-19 who met the criteria for hospital discharge (including two consecutive negative RT-PCR results) reverted to SARS-CoV-2 positivity, indicating a potential asymptomatic carrier state. It remains to be determined whether patients with recurrent SARS-CoV-2 RNA positivity remain infectious after discharge. Furthermore, the clinical and radiological characteristics of the COVID-19 patients with recurrence is largely unknown.

Herein, we retrospectively analyzed 1087 patients with confirmed COVID-19 and explored the clinical course and risk factors of SARS-CoV-2 RNA recurrence by RT-PCR during post-discharge isolation.

\section{RESULTS}

\section{Clinico-demographic characteristics of patients}

A total of 1087 consecutive COVID-19 pneumonia patients positive for SARS-CoV-2 RNA were enrolled in this study. The median age of the cohort was 60 years (9 to 100 years; IQR - 49-69 years) and $635(58.4 \%$ ) of the patients were women. The majority $(83.1 \%)$ of the cases were mild, whereas the proportion of severe and critical cases were $13.2 \%$ and $3.7 \%$ respectively. Most patients $(874,80.4 \%)$ had bilateral pulmonary infiltration on the chest CT, while $730(67.2 \%)$ and 525 patients $(48.3 \%)$ respectively showed ground-glass appearance and consolidation. In addition, 887 out of $1007(88.1 \%)$ patients were positive for serum IgG, while 797 out of 1057 (75.4\%) patients were positive for serum IgM against COVID 19.

The median length of hospitalization was 12 days (1-38 days; IQR, 8-17 days), and 20 patients died during hospitalization whereas 1067 were discharged. The total mortality rate was $1.8 \%$ and the discharge rate was $98.2 \%$. Among the fatalities, 5 patients were graded as severe with mortality rate of $3.5 \%$, and 15 were critical cases with a high mortality rate of $37.5 \%$. The total mortality rate of the severe and critical cases was $10.6 \%$. The median age of the deceased patients was 83 years (65 to 92 years; IQR, 79.3-87.8 years), which was significantly higher than that of the discharged patients $(\mathrm{P}<0.001)$. The main causes of deaths were multiple organ failure (MOSF), most commonly affecting the lungs, heart, liver and kidneys. Other clinical features, laboratory examinations and imaging findings are summarized in Supplementary Table 1.

\section{Characteristics of patients with SARS-CoV-2 RNA recurrence}

Eighty-one (7.6\%) of the discharged patients reverted to SARS-CoV-2 RNA positive after two negative RT-PCR tests during the post-discharge isolation period. The median age of the recurring cases was 62 years (range 16-90 years; IQR, 50.5-68 years), and $51(63.0 \%)$ were female. Twenty (24.7\%) patients had accompanying hypertension and $9(11.1 \%)$ had diabetes. Furthermore, $84.0 \%$ (68), $14.8 \%$ (12) and $1.2 \%$ (1) of the cases were mild, severe and critical respectively. Most of these patients had the initial symptoms of COVID-19 infection prior to positive SARS-CoV-2 RNA diagnosis, and only 15 (18.5\%) were asymptomatic when first diagnosed. Before hospitalization, pulmonary infection was confirmed in 70 patients via CT scan, and $65(65.3 \%)$ received anti-viral agents.

Laboratory and CT imaging results from the inpatient hospital-stay are summarized in Table 1 . Seven $(8.6 \%)$ patients had lymphocytopenia and only 4 (4.9\%) patients had neutrophilia. High-sensitivity CRP was elevated in 8 (9.9\%) patients, and the ESR, procalcitonin and IL-6 levels were increased in $27(33.3 \%), 14(17.3 \%)$ and 11 $(13.6 \%)$ patients. Furthermore, $10(12.3 \%)$ patients developed liver injury with elevated ALT, 4 (4.9\%) demonstrated myocardial damage with elevated AccuTell troponin, and $11(13.6 \%)$ patients had kidney injury with elevated serum BUN and creatinine levels. CT images revealed consolidation, ground-glass opacity and bilateral pulmonary infiltration in 49 (60.5\%), 56 (69.1\%) and $70(86.4 \%)$ patients, respectively. Finally, 72 of 77 (93.5\%) patients were positive for serum IgG, whereas 68 of $79(86.1 \%)$ were positive for serum IgM against COVID-19.

\section{Clinical course of patients with SARS-CoV-2 recurrence}

As shown in Figure 1, the median length of hospitalization for patients that reverted to SARS-CoV2 RNA positive state was 12 days (range, 4-27 days; IQR, 7-17 days). The median duration from discharge to recurrence was 9 days (range, 3-18 days; IQR, 7-10 days), and that from the onset of illness to RT-PCR confirmation was 11 days (range, 0-57 days; IQR, 1.521 days) (Figure 2A). In addition, the time from illness onset to complete RNA negative status was 33 days (range, 6-82 days; IQR, 20-41 days), and from illness onset to recurrence was 50 days (range, 21-95 days; IQR, 36.5-59.5 days). As shown in Figure 2B, the 
Table 1. Clinico-demographic characteristics of patients with recurrence of SARS-CoV-2 RNA positivity.

\begin{tabular}{|c|c|c|}
\hline Variables & No. $(n=81)$ & Percentage (\%) \\
\hline \multicolumn{3}{|l|}{ General features } \\
\hline \multicolumn{3}{|l|}{ Clinical severity of disease } \\
\hline Mild & 68 & $84.0 \%$ \\
\hline Severe & 12 & $14.8 \%$ \\
\hline Critical & 1 & $1.2 \%$ \\
\hline \multicolumn{3}{|l|}{ Age } \\
\hline Median (IQR) & $62.0(50.5-68.0)$ & \\
\hline \multicolumn{3}{|l|}{ Gender } \\
\hline Male & 30 & $37.0 \%$ \\
\hline Female & 51 & $63.0 \%$ \\
\hline \multicolumn{3}{|l|}{ Hypertension } \\
\hline Yes & 20 & $24.7 \%$ \\
\hline No & 61 & $75.3 \%$ \\
\hline \multicolumn{3}{|l|}{ Diabetes } \\
\hline Yes & 9 & $11.1 \%$ \\
\hline No & 72 & $88.8 \%$ \\
\hline \multicolumn{3}{|l|}{ Illness onset } \\
\hline \multicolumn{3}{|l|}{ Fever } \\
\hline Yes & 41 & $50.6 \%$ \\
\hline No & 40 & $49.4 \%$ \\
\hline \multicolumn{3}{|l|}{ Cough } \\
\hline Yes & 44 & $54.3 \%$ \\
\hline No & 37 & $45.7 \%$ \\
\hline \multicolumn{3}{|l|}{ Chest congestion } \\
\hline Yes & 18 & $22.2 \%$ \\
\hline No & 63 & $77.8 \%$ \\
\hline \multicolumn{3}{|l|}{ Weak } \\
\hline Yes & 34 & $42.5 \%$ \\
\hline No & 46 & $57.5 \%$ \\
\hline \multicolumn{3}{|l|}{ Muscular soreness } \\
\hline Yes & 15 & $18.5 \%$ \\
\hline No & 66 & $81.5 \%$ \\
\hline \multicolumn{3}{|l|}{ Pulmonary infection (CT) } \\
\hline Yes & 70 & $86.4 \%$ \\
\hline No & 5 & $6.2 \%$ \\
\hline Unknown & 6 & $7.4 \%$ \\
\hline \multicolumn{3}{|l|}{ Anti-virus therapy } \\
\hline Yes & 53 & $65.4 \%$ \\
\hline No & 15 & $18.5 \%$ \\
\hline Unknown & 13 & $16.0 \%$ \\
\hline \multicolumn{3}{|l|}{ In hospital } \\
\hline \multicolumn{3}{|l|}{ Fever } \\
\hline $\operatorname{Yes}\left(>=37.3^{\circ} \mathrm{C}\right.$ once or more $)$ & 18 & $22.2 \%$ \\
\hline No & 63 & $77.8 \%$ \\
\hline \multicolumn{3}{|l|}{ Internal visceral dysfunctions } \\
\hline Yes & 30 & $37.0 \%$ \\
\hline No & 51 & $63.0 \%$ \\
\hline Comorbid diseases & & \\
\hline Yes & 46 & $56.8 \%$ \\
\hline No & 35 & $43.2 \%$ \\
\hline$\underset{<4}{\text { White blood cell count, } \times 10^{9} \text { pe }}$ & & \\
\hline $4-10$ & 6 & $7.4 \%$ \\
\hline$>10$ & 71 & $87.7 \%$ \\
\hline Unknown & 3 & $3.7 \%$ \\
\hline & 1 & $1.2 \%$ \\
\hline Neutrophil count, $\times 10^{9}$ per $L$ & & \\
\hline$<1.8$ & 3 & $3.7 \%$ \\
\hline $1.8-6.3$ & 73 & $90.1 \%$ \\
\hline$>6.3$ & 4 & $4.9 \%$ \\
\hline Unknown & 1 & $1.2 \%$ \\
\hline $\begin{array}{l}\text { Lymphocyte count, } \times 10^{9} \text { per } L \\
<1.1\end{array}$ & 7 & $8.6 \%$ \\
\hline
\end{tabular}




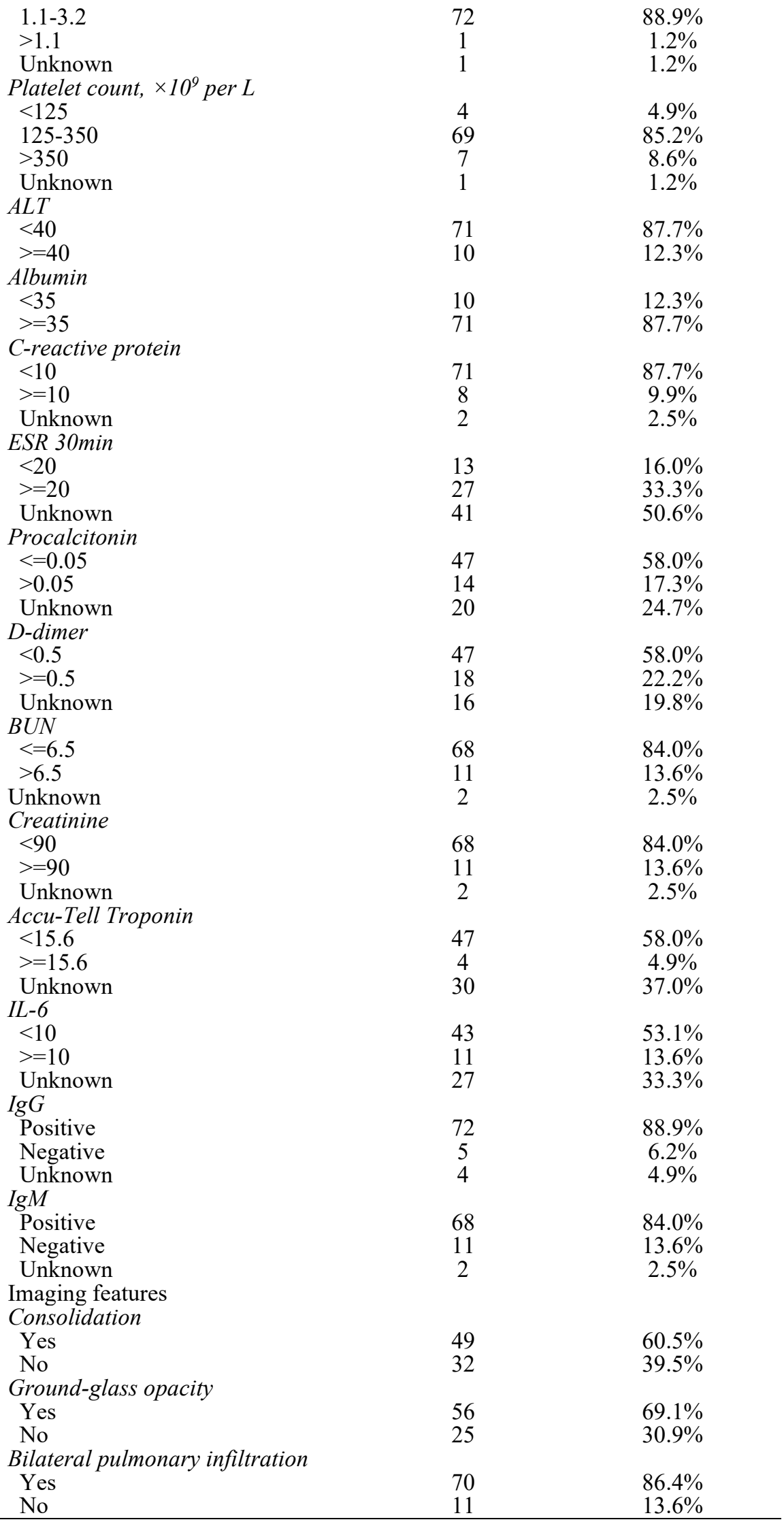


median duration from initial RT-PCR diagnosis to recurrence was 36 days (range, 16-64 days; IQR, 26.545 days). In addition, the median duration between the initial diagnostic RT-PCR and complete RNA negative status was 17 days (range, 1-45 days; IQR, 8-29 days), while that between complete RNA negative status and recurrence was 12 days (range, 4-27 days; IQR, 7-17 days).

Amongst these 81 patients, 37 (45.7\%) received oxygen support. However, no invasive mechanical ventilation (IMV) or IMV with extracorporeal membrane

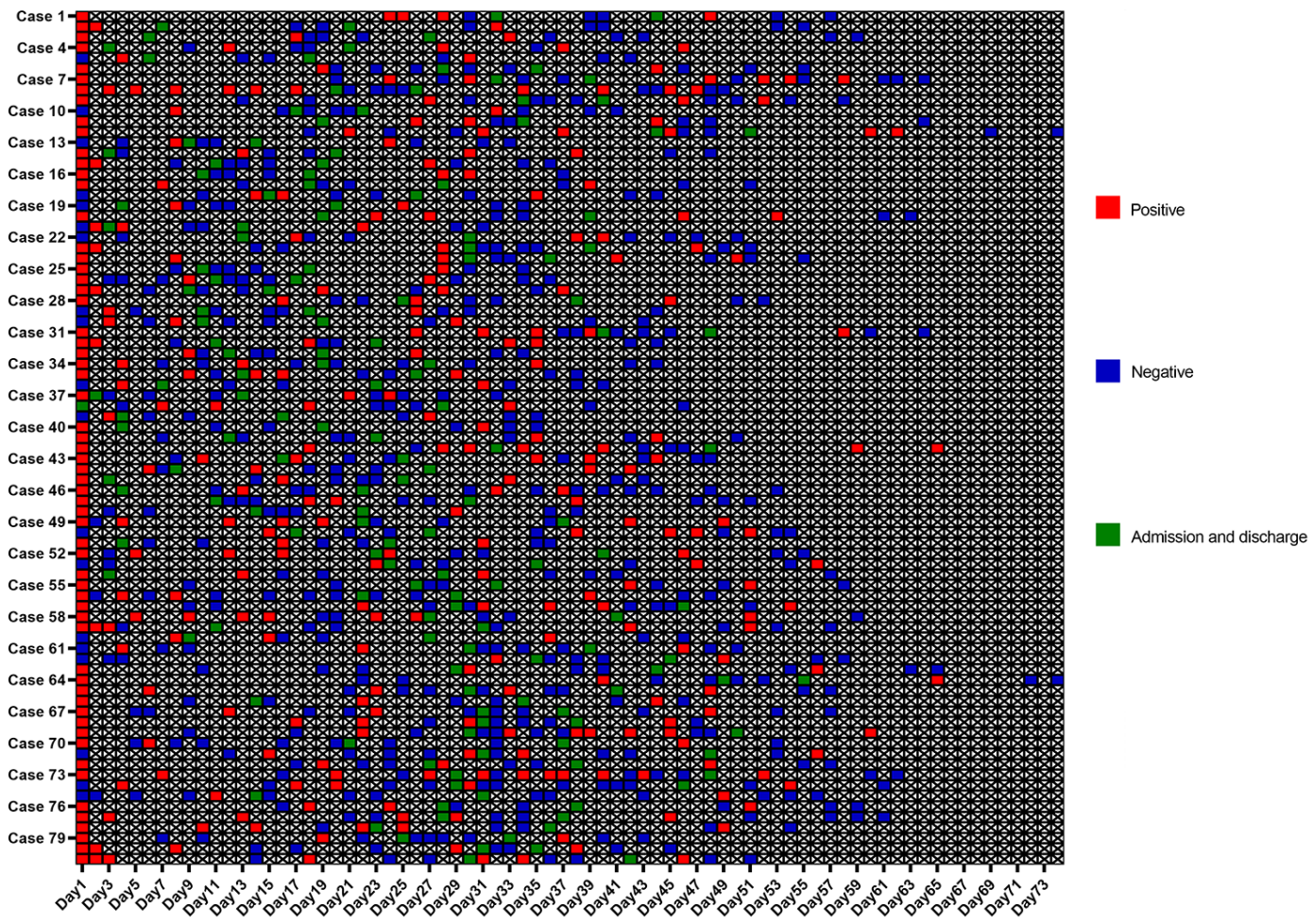

Figure 1. Individual duration of viral shedding and positive SARS-CoV-2 RNA recurrence from illness onset after discharge. The timing and results of RT-PCR examinations for SARS-CoV-2 RNA in details. SARS-CoV-2=severe acute respiratory syndrome coronavirus 2. RT-PCR=reverse transcription-polymerase chain reaction.
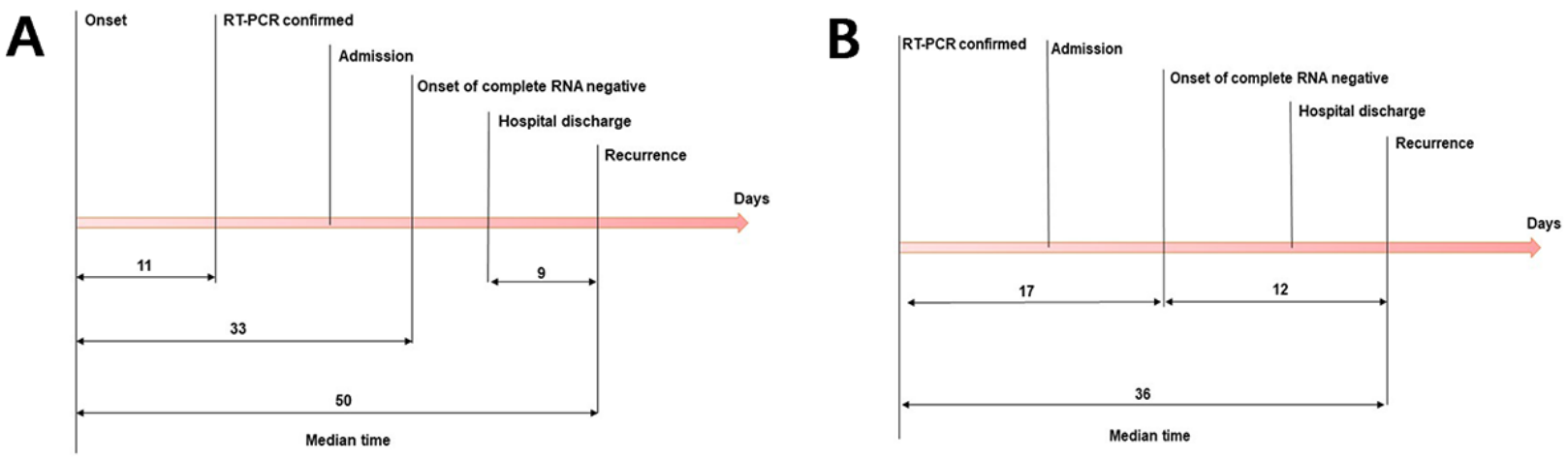

Figure 2. The median duration of different stages in patients with recurrence of positive SARS-CoV-2 RNA after discharge. (A) The median duration from illness onset to initial RT-PCR confirmation, onset of complete RNA negative status and recurrent RT-PCR positivity after discharge, and from discharge to recurrence. (B) The median duration from initial RT-PCR confirmation to onset of complete RNA negative status and recurrent RT-PCR positivity after discharge, and from onset of complete RNA negative status to recurrence. SARS-CoV$2=$ severe acute respiratory syndrome coronavirus 2 . RT-PCR=reverse transcription-polymerase chain reaction. 
oxygenation (ECMO) was used. The optimal antiviral therapy was administered in $69(85.2 \%)$ patients, including arbidol hydrochloride (40 patients, 49.4\%), interferon alfa (17 patients, $21.0 \%$ ), entecavir/tenofovir (7 patients, 8.6\%) and oseltamivir (5 patients, 6.2\%). Fifty-one patients $(63 \%)$ were treated with Chinese patented drugs, such as Lianhuaqingwen capsule. Vitamin C was given to $41(50.6 \%)$ patients, and immunomodulators like thymopentin and immunoglobulin were administrated to 8 (9.9\%) patients.

\section{Associated risk factors with recurrence of positive SARS-CoV-2 RNA}

As shown in Table 2, positive SARS-CoV-2 RNA recurrence correlated positively with serum IL-6 level $(\mathrm{P}=0.010)$ and $\mathrm{CT}$ imaging depicting consolidation $(\mathrm{P}=0.031) . \quad$ In the univariate analysis, elevated lymphocyte count $(\mathrm{P}=0.194, \mathrm{OR}=1.644 ; 95 \% \mathrm{CI}, 0.776$ 3.484), elevated serum IL-6 ( $\mathrm{P}=0.013, \mathrm{OR}=2.504 ; 95 \%$ CI, 1.218-5.150), consolidation on CT imaging $(\mathrm{P}=0.033, \quad \mathrm{OR}=1.655 ; 95 \% \quad \mathrm{CI}, \quad 1.042-2.629)$ and bilateral pulmonary infiltration $(\mathrm{P}=0.196, \mathrm{OR}=1.540$; 95\% CI, 0.800-2.966) were identified as potential risk factors for recurrence of SARS-CoV-2 RNA positivity (Table 3). Multivariate analysis concluded that elevated lymphocyte count $(\mathrm{P}=0.038$, OR $=2.321 ; 95 \% \mathrm{CI}, 1.048$ 5.138), serum IL-6 level ( $\mathrm{P}=0.004, \mathrm{OR}=3.050 ; 95 \% \mathrm{CI}$, 1.432-6.499) and consolidation features on $\mathrm{CT}$ imaging $(\mathrm{P}=0.038, \mathrm{OR}=1.641 ; 95 \% \mathrm{CI}, 1.028-2.620)$ were the independent risk factors of recurrence (Table 4).

\section{DISCUSSION}

In this study, we have provided comprehensive data on the demographic and clinical characteristics of 1087 consecutive COVID-19 patients from Wuhan, China. The majority $(83.1 \%)$ of the cases in our cohort were mild, and the overall mortality rate of the severe and critical cases was $10.6 \%$. The mortality rate of the entire cohort was $1.8 \%$, which is consistent to one previous study [4] but lower than that reported in other studies $[5,12]$. This difference can be partly attributed to the higher proportion of severe cases in the other cohorts, as well as the greater medical resources that were allocated in the later stages of this pandemic wherein we enrolled patients for our study. Liang WH et al. [13] reported that the mortality of COVID-19 patients outside of the Hubei Province was limited to $0.3 \%$, as strict public health interventions were initiated in order to prevent further outbreak outside Hubei and adequate medical resources were provided for treatment. In agreement with previous studies that identified older age as a risk factor of mortality in COVID-19 patients $[6,14]$, the median age of the deceased patients in our cohort was
83 years, distinctly higher than that of the discharged patients $(\mathrm{P}<0.001)$, which further suggests that a higher age was significantly associated with mortality.

Among the 1067 patients that were discharged on the basis of negative SARS-CoV-2 RNA results, 81 (7.6\%) patients reverted to positive state during their isolation period. Similar findings have been reported previously $[11,15,16]$. However, Yuan $\mathrm{J}$ et al. [16] reported a higher repeat positivity rate of $14.5 \%$ after discharge, which could be on account the smaller cohort of enrolled patients. These persistent asymptomatic viral carriers may pose a risk for potential future outbreaks despite unprecedented public health interventions [17]. Therefore, we explored the clinical course and risk predictors for recurrent SARS-CoV-2 PCR positivity in order to provide new insights into the disease and help guide the clinical practice against future outbreaks.

In our study, the median duration of viral shedding for patients with positive SARS-CoV-2 RNA recurrence was 33 days from the onset of illness to complete RNA negative status. However, the median duration from illness onset to SARS-CoV-2 RNA reversion was 50 days. Previous studies have reported on duration of viral shedding. Zhou $\mathrm{F}$ et al. [6] reported a 20 day median duration of viral shedding in survivors and the longest observed duration was 37 days. Furthermore, Zhou B et al. [18] reported that the median duration of viral shedding was 31 days from illness onset in severe COVID-19 patients. Xu K et al. [19] further showed that 3 out of 4 COVID-19 patients had viral RNA clearance within 21 days of illness onset, and male gender, older age, hypertension, delayed hospital admission, severe illness upon admission, invasive mechanical ventilation and corticosteroid treatment were risk factors for prolonged viral RNA clearance. Our findings underscore the importance of a prolonged treatment or isolation for patients at increased risk of recurrent SARS-CoV-2 RNA positivity.

Nevertheless, we found that age and comorbidities that were previously described to be risk factors of mortality [14] were not identified as significant risk factors when compared to patients without reversion. Instead, high serum IL-6 levels, lymphocyte count greater than $1.1 * 10^{8} / \mathrm{L}$ and consolidation on $\mathrm{CT}$ imaging during hospitalization were associated with a higher likelihood of recurrent SARS-CoV-2 RNA positivity after discharge. This is consistent with a previous study that showed that the lymphocyte count prior to discharge was positively correlated with the time to virus reappearance, which confirms the role of lymphocytes in the potential recurrence of SARS-CoV-2 RNA positivity [16]. Other factors that influence the host defense against viral infections, such as clinical severity 
Table 2. Correlations between clinical characteristics and recurrence of SARS-CoV-2 RNA positivity in discharged patients.

\begin{tabular}{|c|c|c|c|c|}
\hline Variables & No. $(n=1067)$ & $\begin{array}{c}\text { No recurrence } \\
n=986 \\
\end{array}$ & $\begin{array}{c}\text { Recurrence } \\
\mathrm{n}=\mathbf{8 1}\end{array}$ & $P$ value \\
\hline \multirow{2}{*}{\multicolumn{5}{|c|}{ General features }} \\
\hline \multicolumn{3}{|l|}{ Clinical severity of disease } & & \\
\hline Mild & 903 & 835 & 68 & \multirow{3}{*}{0.684} \\
\hline Severe & 139 & 127 & 12 & \\
\hline Critical & 25 & 24 & 1 & \\
\hline \multicolumn{5}{|l|}{ Age } \\
\hline Median (IQR) & $60.0(49.0-68.0)$ & $60.0(49.0-68.0)$ & $62.0(50.5-68.0)$ & 0.700 \\
\hline \multicolumn{5}{|l|}{ Gender } \\
\hline Male & 440 & 410 & 30 & \multirow[t]{2}{*}{0.424} \\
\hline Female & 627 & 576 & 51 & \\
\hline \multicolumn{5}{|l|}{ Hypertension } \\
\hline Yes & 331 & 311 & 20 & \multirow[t]{2}{*}{0.200} \\
\hline No & 736 & 675 & 61 & \\
\hline \multicolumn{5}{|l|}{ Diabetes } \\
\hline Yes & 135 & 126 & 9 & \multirow[t]{2}{*}{0.664} \\
\hline No & 932 & 860 & 72 & \\
\hline \multicolumn{5}{|l|}{ In hospital } \\
\hline Fever & & & & \multirow{3}{*}{0.853} \\
\hline $\mathrm{Yes}\left(>=37.3^{\circ} \mathrm{C}\right.$ once or more $)$ & 246 & 228 & 18 & \\
\hline No & 821 & 758 & 63 & \\
\hline \multicolumn{5}{|l|}{ Internal visceral dysfunctions } \\
\hline Yes & 343 & 313 & 30 & \multirow[t]{2}{*}{0.327} \\
\hline No & 724 & 673 & 51 & \\
\hline \multicolumn{5}{|l|}{ Comorbid diseases } \\
\hline Yes & 560 & 514 & 46 & 0.419 \\
\hline No & 507 & 472 & 35 & \\
\hline$\underset{<4}{W h i t e}$ blood cell count, $\times 10^{9}$ pe & & & & \\
\hline $\begin{array}{c}<4 \\
4-10\end{array}$ & 100 & 94 & 6 & 0570 \\
\hline $\begin{array}{l}4-10 \\
>10\end{array}$ & 927 & 856 & 71 & 0.579 \\
\hline Unknown & 24 & 21 & 3 & \\
\hline & 16 & 15 & 1 & \\
\hline $\begin{array}{l}\text { Neutrophil count, } \times 10^{5} \text { per } L \\
<=6.3\end{array}$ & 994 & 918 & 76 & \\
\hline$>6.3$ & 57 & 53 & 4 & 1.000 \\
\hline Unknown & 16 & 15 & 1 & \\
\hline Lymphocyte count, $\times 10^{9}$ per $L$ & & & & \\
\hline$<=1.1$ & 158 & 150 & 8 & \\
\hline$>1.1$ & 894 & 821 & 72 & 0.190 \\
\hline Unknown & 15 & 15 & 1 & \\
\hline Platelet count, $\times 10^{9}$ per $L$ & & & & \\
\hline$<125$ & 44 & 40 & 4 & \\
\hline $125-350$ & 956 & 886 & 69 & 0.297 \\
\hline$>350$ & 52 & 45 & 7 & \\
\hline Unknown & 15 & 15 & 1 & \\
\hline$A L T$ & & & & \\
\hline$<40$ & 852 & 781 & 71 & \\
\hline$>=40$ & 181 & 171 & 10 & 0.202 \\
\hline Unknown & 34 & 34 & 0 & \\
\hline Albumin & & & & \\
\hline$<35$ & 154 & 144 & 10 & \\
\hline$>=35$ & 880 & 809 & 71 & 0.502 \\
\hline Unknown & 33 & 33 & 0 & \\
\hline C-reactive protein & & & & \\
\hline$<10$ & 914 & 843 & 71 & \\
\hline$>=10$ & 121 & 113 & 8 & 0.653 \\
\hline Unknown & 32 & 30 & 2 & \\
\hline ESR 30min & & & & \\
\hline & 176 & 163 & & \\
\hline$>=20$ & 282 & 255 & 27 & 0.420 \\
\hline Unknown & 609 & 568 & 41 & \\
\hline Procalcitonin & & & & 0.571 \\
\hline
\end{tabular}




\begin{tabular}{|c|c|c|c|c|}
\hline$<=0.05$ & 589 & 542 & 47 & \\
\hline$>0.05$ & 207 & 193 & 14 & \\
\hline Unknown & 271 & 251 & 20 & \\
\hline \multicolumn{5}{|l|}{$D$-dimer } \\
\hline$<0.5$ & 507 & 460 & 47 & \multirow{3}{*}{0.339} \\
\hline$>=0.5$ & 250 & 232 & 18 & \\
\hline Unknown & 310 & 294 & 16 & \\
\hline \multicolumn{5}{|l|}{ BUN } \\
\hline$<=6.5$ & 853 & 785 & 68 & \multirow{3}{*}{0.822} \\
\hline$>6.5$ & 148 & 137 & 11 & \\
\hline Unknown & 66 & 64 & 2 & \\
\hline \multicolumn{5}{|l|}{ Creatinine } \\
\hline$<90$ & 907 & 839 & 68 & \multirow{3}{*}{0.150} \\
\hline$>=90$ & 94 & 83 & 11 & \\
\hline Unknown & 66 & 64 & 2 & \\
\hline \multicolumn{5}{|c|}{ Accu-Tell Troponin } \\
\hline$<15.6$ & 590 & 543 & 47 & \multirow{3}{*}{1.000} \\
\hline$>=15.6$ & 54 & 50 & 4 & \\
\hline Unknown & 423 & 393 & 30 & \\
\hline \multicolumn{5}{|l|}{$I L-6$} \\
\hline$<10$ & 552 & 509 & 43 & \multirow{3}{*}{0.010} \\
\hline$>=10$ & 63 & 52 & 11 & \\
\hline Unknown & 452 & 425 & 27 & \\
\hline \multicolumn{5}{|c|}{ Imaging features } \\
\hline \multicolumn{5}{|c|}{ Consolidation } \\
\hline Yes & 520 & 471 & 49 & \multirow{3}{*}{0.031} \\
\hline No & 541 & 509 & 32 & \\
\hline Unknown & 6 & 6 & 0 & \\
\hline \multicolumn{5}{|c|}{ Ground-glass opacity } \\
\hline Yes & 720 & 664 & 56 & \multirow{3}{*}{0.798} \\
\hline No & 341 & 316 & 25 & \\
\hline Unknown & 6 & 6 & 0 & \\
\hline \multicolumn{5}{|c|}{ Bilateral pulmonary infiltration } \\
\hline Yes & 859 & 789 & 70 & \multirow{3}{*}{0.193} \\
\hline No & 202 & 191 & 11 & \\
\hline Unknown & 6 & 6 & 0 & \\
\hline
\end{tabular}

of the disease, CRP, D-dimer level etc., were not significantly different between the recurrent versus non-recurrent groups. IL- 6 is one of the major proinflammatory cytokines that are instrumental in clearing pathogens. However, the rapid multiplication of SARS-CoV-2 in the lower respiratory tract leads to excessive IL-6 production, which triggers an acute severe systemic inflammatory response known as cytokine release syndrome (CRS) [20]. In fact, the increased serum IL-6 levels in severe and critical COVID-19 patients is associated with poor outcomes $[21,22]$, which was also observed during severe acute respiratory syndrome (SARS) outbreak [23]. Concurrently, lymphopenia is also common in patients with COVID-19, especially in severe and critical cases $[5,22,24]$, suggesting a dysregulated immune response in this sub-cohort. In our study however, only $175(16.1 \%)$ patients showed a decrease in lymphocyte count, which again may be can be attributed to the fewer severe cases. Interestingly, the discharged patients with recurrence of positive SARS-CoV-2 RNA had an elevated serum IL-6 level and lymphocyte count compared to those with no recurrence, indicating that the immune system may still be actively involved in clearing the infection. It is also possible that the immune responses can suppress but not completely eradicate SARS-CoV-2, which may have led to the falsenegative results due to lower viral loads. Once the virus started replicating again, the RT-PCR results reverted to positive in the discharged patients.

The chest CT imaging of COVID-19 pneumonia is a useful preliminary diagnostic tool that has lowered the rate of missed diagnoses [25]. Features of consolidation on CT imaging are associated with critical disease [26]. Progression of consolidation might indicate further infiltration of the lung parenchyma and lung interstitium due to virus invasion into the respiratory epithelium, which is characterized by diffuse alveolar damage and necrotizing bronchitis. This eventually leads to complete permeation of the alveoli with the inflammatory exudate $[27,28]$. Therefore, SARS-CoV2 may persist in the respiratory epithelium during lung consolidation in the recovery phase of the infection, which eventually results in the recurrence of positive SARS-CoV-2 RNA after discharge. Interestingly, most patients with recurrence had fluctuating positive and 
Table 3. Univariate regression analysis for risk factors of patients with recurrence of SARS-CoV-2 RNA positivity.

\begin{tabular}{lccc}
\hline Variables & No. & $\begin{array}{c}\text { Univariate OR } \\
(\mathbf{9 5 \%} \text { CI) }\end{array}$ & P value \\
\hline Age & 1067 & $1.000(0.985-1.015)$ & 0.995 \\
Gender & 1067 & $1.210(0.757-1.933)$ & 0.425 \\
Clinical severity of disease & 1067 & $0.976(0.579-1.645)$ & 0.927 \\
Hypertension & 1067 & $0.712(0.422-1.200)$ & 0.202 \\
Diabetes & 1067 & $0.853(0.416-1.749)$ & 0.665 \\
Fever & 1067 & $0.950(0.551-1.637)$ & 0.853 \\
Internal visceral dysfunctions & 1067 & $1.265(0.790-2.025)$ & 0.328 \\
Comorbid diseases & 1067 & $1.207(0.764-1.906)$ & 0.420 \\
Neutrophil count, $\times 10^{9}$ per L & 1051 & $0.912(0.321-2.587)$ & 0.862 \\
Lymphocyte count, $\times 10^{9}$ per L & 1051 & $1.644(0.776-3.484)$ & $\mathbf{0 . 1 9 4}$ \\
Platelet count, $\times 10^{9}$ per L & 1051 & $1.417(0.676-2.969)$ & 0.356 \\
ALT & 1033 & $0.643(0.325-1.273)$ & 0.205 \\
Albumin & 1034 & $1.264(0.637-2.508)$ & 0.503 \\
C-reactive protein & 1035 & $0.841(0.394-1.792)$ & 0.653 \\
ESR 30min & 458 & $1.328(0.666-2.647)$ & 0.421 \\
Procalcitonin & 796 & $0.837(0.450-1.553)$ & 0.572 \\
D-dimer & 757 & $0.759(0.431-1.337)$ & 0.340 \\
Accu-Tell Troponin & 644 & $0.924(0.320-2.671)$ & 0.884 \\
IL-6 & 615 & $2.504(1.218-5.150)$ & 0.013 \\
Consolidation & 1061 & $1.655(1.042-2.629)$ & 0.033 \\
Ground-glass opacity & 1061 & $1.066(0.653-1.740)$ & 0.798 \\
Bilateral pulmonary infiltration & 1061 & $1.540(0.800-2.966)$ & $\mathbf{0 . 1 9 6}$ \\
\hline
\end{tabular}

Table 4. Multivariate regression analysis for risk factors of patients with recurrence of SARS-CoV-2 RNA positivity.

\begin{tabular}{lcc}
\hline Variables & $\begin{array}{c}\text { Multivariate OR } \\
(\mathbf{9 5 \%} \mathbf{C I})\end{array}$ & P value \\
\hline IL-6 & Reference & \\
$<10$ & $3.050(1.432-6.499)$ & 0.004 \\
$>=10$ & Reference & \\
$\quad$ Consolidation & $1.641(1.028-2.620)$ & 0.038 \\
$\quad$ No & Reference & \\
$\quad$ Yes & $2.321(1.048-5.138)$ & 0.038 \\
$\quad<y$ mphocyte count, $\times 10^{9}$ per L & Reference & \\
$>1.1$ & $1.482(0.764-2.871)$ & 0.244 \\
Bilateral pulmonary infiltration &
\end{tabular}

negative results in the course of the disease, especially in cases 7, 8 and 41 (Figure 1). This is a potential sign of recurrent SARS-CoV-2 positivity after discharge, and also partly ruled out the randomly error probability in RT-PCR detection for one case. Thus, the infected patients may have already been immune to the virus and require a period for complete recovery. However, if the immune response cannot deal with the recurrence, further treatment may be still needed.

\section{Limitations}

This study has a few limitations that ought to be noted. First, this study was conducted at a single-center hospital which may have introduced a selection bias that influenced the clinical outcomes. A larger multi-center or even global cohort study of COVID-19 patients would help further define the clinical characteristics and risk factors of recurrence. Second, only multipoint throat-swab 
specimens were tested which increases the risk of false negative results. Therefore, multisite samples should be collected for RT-PCR detection, such as the fecal SARSCoV-2 RNA test for patients with gastrointestinal symptoms [29]. Third, the retrospective design and initial lack of guidelines for drug administration made it difficult to analyze the impact of treatment regimens on the recurrence of positive SARS-CoV-2 RNA.

\section{CONCLUSIONS}

Elevated lymphocyte counts and serum IL-6 level, and consolidation on chest CT were associated with a greater risk of recurrent SARS-CoV-2 RNA positivity, possibly due to a balance between immune regulation and virus toxicity. For patients with a higher risk of recurrence, a prolonged treatment or isolation period for at least 50 days after illness onset is recommended in order to identify patients that may pose a risk for future outbreaks.

\section{MATERIALS AND METHODS}

\section{Study design and participants}

A total of 1087 consecutive COVID-19 patients diagnosed by SARS-CoV-2 RNA detection in accordance with the interim guidelines of World Health Organization at the Guanggu Branch of Hubei Province Maternity and Childcare Hospital (Wuhan, China) were retrospectively enrolled. All patients had been discharged or had died between February 24, 2020 and March 31, 2020. This study was approved by the Research Ethics Committee of Guanggu Branch of Hubei Province Maternity and Childcare Hospital and was granted with a waiver of informed consent from study participants.

\section{Data collection and follow-up}

The epidemiological, radiographic, laboratory, treatment and treatment outcome data of these patients were extracted from medical records and through direct communication in order to establish a database. The SARS-CoV-2 RNA RT-PCR records from discharge to April 15, 2020 were obtained from the Health Wuhan App, a database containing all real-time results about SARS-CoV-2 RNA tests conducted in Wuhan. The patients were assigned a number for confidentiality. All data were evaluated by two authors (JC and QC) and thereafter by a third researcher (NP) in case of any differences in interpretation.

\section{Clinical tests}

In accordance with the standard procedure, throat-swab specimens were obtained and tested for SARS-CoV-2 infection using RT-PCR by the Academy of Military Medical Sciences and hospital laboratory [14]. The test was repeated during the hospital stay and after clinical remission of symptoms at 24-hour intervals. In addition, serum levels of SARS-CoV-2-specific IgM/IgG measured during hospitalization with the indirect enzyme-linked immunosorbent assay (ELISA) protocol using the $\mathrm{N}$ protein of SARS-CoV-2 as the coating antigen. Routine blood tests were performed to determine complete blood counts (including white blood cells, neutrophils, lymphocytes, monocytes and platelets), biochemical indices (liver function, renal function and electrolyte levels), coagulation indices, high-sensitivity C-reactive protein (CRP), erythrocyte sedimentation rate (ESR), procalcitonin, myocardial enzymes, D-dimer and interleukin-6 (IL-6). Computed tomography (CT) scans were routinely performed as recommended by the attending physician.

\section{Clinical definitions}

The patients were discharged based on the following criteria: 1) no fever for at least three days, 2) remission of respiratory symptoms, 3 ) amelioration of pulmonary inflammation on the chest CT scan, 4) two negative SARS-CoV-2 RNA tests at least 24 hours apart, 5) overall good constitution.

The severity of COVID-19 was defined according to the Chinese management guidelines for COVID-19 (version 6.0) [10]. Fever was defined as axillary temperature of at least $37.3^{\circ} \mathrm{C}$. Comorbidities during hospitalization included hypertension, diabetes, hypoproteinaemia $(<25 \mathrm{~g} / \mathrm{L})$, coagulopathy (3-second increase in prothrombin time or a 5-second increase of activated partial thromboplastin time), hyperuricemia (blood trioxypurine $>420 \mu \mathrm{mol} / \mathrm{L}$ or $>360 \mu \mathrm{mol} / \mathrm{L}$ in males and females respectively), anemia (according to WHO guidelines [30]), acute respiratory distress syndrome (ARDS; diagnosed according to the Berlin Definition [31]), acute liver failure (diagnosed according to EASL Clinical Practical Guidelines [32]), acute kidney injury (diagnosed according to the KDIGO clinical practice guidelines [33]), and acute cardiac injury (diagnosed as previously reported [6])

\section{Statistical analysis}

Continuous and categorical variables were respectively presented as median with interquartile range (IQR) and counts with percentages. The differences between the recurrence and non-recurrence groups were compared using the Pearson Chis-squared test, Fisher's exact test or Mann-Whitney U test as appropriate. The risk factors associated with the recurrence of positive SARS-CoV-2 RNA were identified using univariate analysis, and 
variables with $\mathrm{P}<0.2$ were selected for multivariate logistic regression model. Missing data was not included in any of the analyses. A two-sided $\mathrm{P}<0.05$ was considered statistically significant. All statistical analyses were performed using the SPSS v21.0 software (IBM Corporation, Armonk, NY, USA), and the figures were plotted using the GraphPad Prism 8.0 software (GraphPad Software, La Jolla, CA, USA).

\section{AUTHOR CONTRIBUTIONS}

$\mathrm{JC}, \mathrm{XX}, \mathrm{NP}$, and $\mathrm{ZC}$ conceived and designed the research. JC, XX, JH, FX, HL, NL, HZ, JL, JX, NP and ZC collected and analyzed data. JC, QC, NP, and ZC participated in evaluation of results. JC, QC, and NP wrote the manuscript, and all authors contributed to manuscript revision, read and approved the submitted version.

\section{ACKNOWLEDGMENTS}

We acknowledge all health-care workers involved in the diagnosis and treatment of patients in Wuhan; and we thank Joseph R Habib (Johns Hopkins University School of Medicine, Baltimore, Maryland, USA) for review and revise of the manuscript. This manuscript has been published in the preprint of medRxiv (doi.org/10.1101/2020.05.08.20095018) and SSRN (doi.org/10.2139/ssrn.3588539).

\section{CONFLICTS OF INTEREST}

We declare no conflicts of interest.

\section{FUNDING}

This study was funded by the Guanggu Branch of Hubei Province Maternity and Childcare Hospital Fund (2020FYGG-085).

\section{REFERENCES}

1. Zhu N, Zhang D, Wang W, Li X, Yang B, Song J, Zhao X, Huang B, Shi W, Lu R, Niu P, Zhan F, Ma X, et al, and China Novel Coronavirus Investigating and Research Team. A novel coronavirus from patients with pneumonia in China, 2019. N Engl J Med. 2020; 382:727-33.

https://doi.org/10.1056/NEJMoa2001017

PMID: $\underline{31978945}$

2. Phelan AL, Katz R, Gostin LO. The novel coronavirus originating in Wuhan, China: challenges for global health governance. JAMA. 2020. [Epub ahead of print]. https://doi.org/10.1001/iama.2020.1097 PMID: $\underline{31999307}$
3. World Health Organization. Novel Coronavirus (2019nCoV) https://www.who.int/emergencies/diseases/ novel-coronavirus-2019.

4. Guan WJ, Ni ZY, Hu Y, Liang WH, Ou CQ, He JX, Liu L, Shan $H$, Lei CL, Hui DS, Du B, Li L, Zeng G, et al, and China Medical Treatment Expert Group for Covid-19. Clinical characteristics of coronavirus disease 2019 in China. N Engl J Med. 2020; 382:1708-20. https://doi.org/10.1056/NEJMoa2002032 PMID: $\underline{32109013}$

5. Wang $D$, Hu B, Hu C, Zhu F, Liu X, Zhang J, Wang B, Xiang $\mathrm{H}$, Cheng $\mathrm{Z}$, Xiong $\mathrm{Y}$, Zhao $\mathrm{Y}$, Li $\mathrm{Y}$, Wang $\mathrm{X}$, Peng $\mathrm{Z}$. Clinical characteristics of 138 hospitalized patients with 2019 novel coronavirus-infected pneumonia in Wuhan, China. JAMA. 2020; 323:1061-69. https://doi.org/10.1001/jama.2020.1585 PMID:32031570

6. Zhou F, Yu T, Du R, Fan G, Liu Y, Liu Z, Xiang J, Wang Y, Song B, Gu X, Guan L, Wei Y, Li H, et al. Clinical course and risk factors for mortality of adult inpatients with COVID-19 in Wuhan, China: a retrospective cohort study. Lancet. 2020; 395:1054-62. https://doi.org/10.1016/S0140-6736(20)30566-3 PMID:32171076

7. Andersen KG, Rambaut A, Lipkin WI, Holmes EC, Garry RF. The proximal origin of SARS-CoV-2. Nat Med. 2020; 26:450-52. https://doi.org/10.1038/s41591-020-0820-9 PMID: $\underline{2284615}$

8. Forster P, Forster L, Renfrew C, Forster M. Phylogenetic network analysis of SARS-CoV-2 genomes. Proc Natl Acad Sci U S A. 2020; 117:9241-9243. https://doi.org/10.1073/pnas.2004999117 PMID:32269081

9. Li Y, Yao L, Li J, Chen L, Song Y, Cai Z, Yang C. Stability issues of RT-PCR testing of SARS-CoV-2 for hospitalized patients clinically diagnosed with COVID-19. J Med Virol. 2020; 92:903-08. https://doi.org/10.1002/jmv.25786 PMID:32219885

10. National Health Commission of the People's Republic of China. Chinese management guideline for COVID-19 (version 6.0). Feb 19, 2020. http://www.nhc.gov.cn/ yzygi/s7653p/202002/8334a8326dd94d329df351d7da 8aefc2/files/b218cfeb1bc54639af227f922bf6b817.pdf.

11. Lan L, Xu D, Ye G, Xia C, Wang S, Li Y, Xu H. Positive RTPCR test results in patients recovered from COVID-19. JAMA. 2020; 323:1502-03.

https://doi.org/10.1001/jama.2020.2783 PMID: $\underline{2105304}$

12. Chen N, Zhou M, Dong $X$, Qu J, Gong F, Han $Y$, Qiu $Y$, Wang J, Liu Y, Wei Y, Xia J, Yu T, Zhang X, Zhang L. Epidemiological and clinical characteristics of 99 cases 
of 2019 novel coronavirus pneumonia in Wuhan, China: a descriptive study. Lancet. 2020; 395:507-13. https://doi.org/10.1016/S0140-6736(20)30211-7 PMID:32007143

13. Liang WH, Guan WJ, Li CC, Li YM, Liang HR, Zhao Y, Liu $X Q$, Sang $L$, Chen RC, Tang $C L$, Wang $T$, Wang $W$, He $\mathrm{QH}$, et al. Clinical characteristics and outcomes of hospitalised patients with COVID-19 treated in hubei (epicentre) and outside hubei (non-epicentre): a nationwide analysis of China. Eur Respir J. 2020; 55:2000562.

https://doi.org/10.1183/13993003.00562-2020 PMID:32269086

14. Wu C, Chen X, Cai Y, Xia J, Zhou X, Xu S, Huang H, Zhang L, Zhou $X$, Du C, Zhang Y, Song J, Wang S, et al. Risk factors associated with acute respiratory distress syndrome and death in patients with coronavirus disease 2019 pneumonia in Wuhan, China. JAMA Intern Med. 2020; 180:1-11.

https://doi.org/10.1001/jamainternmed.2020.0994 PMID:32167524

15. Chen D, Xu W, Lei Z, Huang Z, Liu J, Gao Z, Peng L. Recurrence of positive SARS-CoV-2 RNA in COVID-19: a case report. Int J Infect Dis. 2020; 93:297-99.

https://doi.org/10.1016/j.ijid.2020.03.003 PMID: $\underline{32147538}$

16. Yuan J, Kou S, Liang Y, Zeng J, Pan Y, Liu L. PCR assays turned positive in 25 discharged COVID-19 patients. Clin Infect Dis. 2020. [Epub ahead of print]. https://doi.org/10.1093/cid/ciaa398 PMID:32266381

17. Pan A, Liu L, Wang C, Guo H, Hao X, Wang Q, Huang J, He N, Yu H, Lin X, Wei S, Wu T. Association of public health interventions with the epidemiology of the COVID-19 outbreak in Wuhan, China. JAMA. 2020; 323:1-9.

https://doi.org/10.1001/jama.2020.6130 PMID:32275295

18. Zhou B, She J, Wang Y, Ma X. The duration of viral shedding of discharged patients with severe COVID-19. Clin Infect Dis. 2020. [Epub ahead of print]. https://doi.org/10.1093/cid/ciaa451 PMID: $\underline{32302000}$

19. Xu K, Chen Y, Yuan J, Yi P, Ding C, Wu W, Li Y, Ni Q, Zou $\mathrm{R}$, Li $X$, Xu M, Zhang $Y$, Zhao $H$, et al. Factors associated with prolonged viral RNA shedding in patients with COVID-19. Clin Infect Dis. 2020. 71:799-806. https://doi.org/10.1093/cid/ciaa351 PMID:32271376

20. Liu B, Li M, Zhou Z, Guan X, Xiang Y. Can we use interleukin-6 (IL-6) blockade for coronavirus disease 2019 (COVID-19)-induced cytokine release syndrome (CRS)? J Autoimmun. 2020; 111:102452. https://doi.org/10.1016/i.jaut.2020.102452 PMID:32291137
21. Chen X, Zhao B, Qu Y, Chen $Y$, Xiong J, Feng $Y$, Men D, Huang $Q$, Liu $Y$, Yang B, Ding J, Li F. Detectable serum SARS-CoV-2 viral load (RNAaemia) is closely correlated with drastically elevated interleukin 6 (IL-6) level in critically ill COVID-19 patients. Clin Infect Dis. 2020. [Epub ahead of print]. https://doi.org/10.1093/cid/ciaa449 PMID:32301997

22. Chen $G$, Wu D, Guo W, Cao Y, Huang D, Wang H, Wang T, Zhang $X$, Chen $\mathrm{H}, \mathrm{Yu} \mathrm{H}$, Zhang $X$, Zhang $\mathrm{M}$, Wu S, et al. Clinical and immunological features of severe and moderate coronavirus disease 2019. J Clin Invest. 2020; 130:2620-29.

https://doi.org/10.1172/JCl137244 PMID:32217835

23. Zhang Y, Li J, Zhan Y, Wu L, Yu X, Zhang W, Ye L, Xu S, Sun $R$, Wang $Y$, Lou J. Analysis of serum cytokines in patients with severe acute respiratory syndrome. Infect Immun. 2004; 72:4410-15.

https://doi.org/10.1128/IAl.72.8.4410-4415.2004 PMID:15271897

24. Yang $P$, Ding $Y, X u Z$, Pu R, Li P, Yan J, Liu J, Meng F, Huang L, Shi L, Jiang $T$, Qin $E$, Zhao $M$, et al. Epidemiological and clinical features of COVID-19 patients with and without pneumonia in Beijing, China. medRxiv. 2020.

https://doi.org/10.1101/2020.02.28.20028068

25. Li Y, Xia L. Coronavirus disease 2019 (COVID-19): role of chest CT in diagnosis and management. AJR Am J Roentgenol. 2020; 214:1280-86.

https://doi.org/10.2214/AJR.20.22954

PMID: $\underline{2130038}$

26. Lyu P, Liu X, Zhang R, Shi L, Gao J. The performance of chest CT in evaluating the clinical severity of COVID-19 pneumonia: identifying critical cases based on CT characteristics. Invest Radiol. 2020; 55:412-21. https://doi.org/10.1097/RLI.0000000000000689 PMID: $\underline{32304402}$

27. Zhou S, Wang $Y$, Zhu $T$, Xia L. CT features of coronavirus disease 2019 (COVID-19) pneumonia in 62 patients in Wuhan, China. AJR Am J Roentgenol. 2020; 214:1287-94. https://doi.org/10.2214/AJR.20.22975 PMID:32134681

28. Koo HJ, Lim S, Choe J, Choi SH, Sung H, Do KH. Radiographic and CT features of viral pneumonia. Radiographics. 2018; 38:719-39. https://doi.org/10.1148/rg.2018170048 PMID:29757717

29. Cheung KS, Hung IF, Chan PP, Lung KC, Tso E, Liu R, Ng YY, Chu MY, Chung TW, Tam AR, Yip CC, Leung KH, Fung $A Y$, et al. Gastrointestinal manifestations of SARS-CoV-2 infection and virus load in fecal samples from a Hong Kong cohort: systematic review and 
meta-analysis. Gastroenterology. 2020; 159:81-95. https://doi.org/10.1053/i.gastro.2020.03.065 PMID: $\underline{32251668}$

30. WHO. Haemoglobin concentrations for the diagnosis of anaemia and assessment of severity. Vitamin and Mineral Nutrition Information System. Geneva, World Health Organization, 2011. (WHO/NMH/NHD/ MNM/11.1).

http://www.who.int/vmnis/indicators/haemoglobin.p df

31. Ranieri VM, Rubenfeld GD, Thompson BT, Ferguson ND, Caldwell E, Fan E, Camporota L, Slutsky AS, and ARDS Definition Task Force. Acute respiratory distress syndrome: the berlin definition. JAMA. 2012; 307:2526-33.

https://doi.org/10.1001/jama.2012.5669

PMID:22797452
32. European Association for the Study of the Liver. Electronic address: easloffice@easloffice.eu; Clinical practice guidelines panel, Wendon, J; Panel members, Cordoba J, Dhawan A, Larsen FS, Manns M, Samuel D, Simpson KJ, Yaron I; EASL Governing Board representative, Bernardi M. EASL Clinical Practical Guidelines on the management of acute (fulminant) liver failure. J Hepatol. 2017; 66:1047-1081. https://doi.org/10.1016/j.jhep.2016.12.003 PMID:28417882

33. Khwaja A. KDIGO clinical practice guidelines for acute kidney injury. Nephron Clin Pract. 2012; 120:c179-84. https://doi.org/10.1159/000339789

PMID:22890468 


\section{SUPPLEMENTARY MATERIAL}

\section{Supplementary Table}

Supplementary Table 1. Clinico-demographic characteristics of all patients with COVID-19 confirmed by RT-PCR.

\begin{tabular}{|c|c|c|}
\hline Variables & No. $(n=1087)$ & Percentage (\%) \\
\hline \multicolumn{3}{|l|}{ General features } \\
\hline \multicolumn{3}{|l|}{ Clinical severity of disease } \\
\hline Mild & 903 & $83.1 \%$ \\
\hline Severe & 144 & $13.2 \%$ \\
\hline Critical & 40 & $3.7 \%$ \\
\hline \multicolumn{3}{|l|}{ Age } \\
\hline Median (IQR) & $60.0(49.0-69.0)$ & \\
\hline \multicolumn{3}{|l|}{ Gender } \\
\hline Male & 452 & $41.6 \%$ \\
\hline Female & 635 & $58.4 \%$ \\
\hline \multicolumn{3}{|l|}{ Hypertension } \\
\hline Yes & 337 & $31.0 \%$ \\
\hline No & 750 & $69.0 \%$ \\
\hline \multicolumn{3}{|l|}{ Diabetes } \\
\hline Yes & 137 & $12.6 \%$ \\
\hline No & 950 & $87.4 \%$ \\
\hline \multicolumn{3}{|l|}{ In hospital } \\
\hline \multicolumn{3}{|l|}{ Fever } \\
\hline $\operatorname{Yes}\left(>=37.3^{\circ} \mathrm{C}\right.$ once or more $)$ & 254 & $23.4 \%$ \\
\hline No & 833 & $76.6 \%$ \\
\hline \multicolumn{3}{|l|}{ Internal visceral dysfunctions } \\
\hline Yes & 363 & $33.4 \%$ \\
\hline No & 724 & $66.6 \%$ \\
\hline \multicolumn{3}{|l|}{ Comorbid diseases } \\
\hline Yes & 580 & $53.4 \%$ \\
\hline No & 507 & $46.6 \%$ \\
\hline \multicolumn{3}{|l|}{ White blood cell count, $\times 10^{9}$ per $L$} \\
\hline$<4$ & 102 & $9.4 \%$ \\
\hline $4-10$ & 938 & $86.3 \%$ \\
\hline$>10$ & 31 & $2.9 \%$ \\
\hline Unknown & 16 & $1.5 \%$ \\
\hline \multicolumn{3}{|l|}{ Neutrophil count, $\times 10^{9}$ per $L$} \\
\hline$<=6.3$ & 1005 & $92.5 \%$ \\
\hline$>6.3$ & 66 & $6.1 \%$ \\
\hline Unknown & 16 & $1.5 \%$ \\
\hline \multicolumn{3}{|l|}{ Lymphocyte count, $\times 10^{9}$ per $L$} \\
\hline$<=1.1$ & 175 & $16.1 \%$ \\
\hline$>1.1$ & 896 & $82.4 \%$ \\
\hline Unknown & 16 & $1.5 \%$ \\
\hline \multicolumn{3}{|l|}{ Platelet count, $\times 10^{9}$ per $L$} \\
\hline$<125$ & 52 & $4.8 \%$ \\
\hline $125-350$ & 967 & $89.0 \%$ \\
\hline$>350$ & 52 & $4.8 \%$ \\
\hline Unknown & 16 & $1.5 \%$ \\
\hline \multicolumn{3}{|l|}{$A L T$} \\
\hline$<40$ & 867 & $79.8 \%$ \\
\hline$>=40$ & 185 & $17.0 \%$ \\
\hline Unknown & 35 & $3.2 \%$ \\
\hline \multicolumn{3}{|l|}{ Albumin } \\
\hline$<35$ & 171 & $15.7 \%$ \\
\hline$>=35$ & 883 & $81.2 \%$ \\
\hline Unknown & 33 & $3.0 \%$ \\
\hline \multicolumn{3}{|l|}{ C-reactive protein } \\
\hline$<10$ & 919 & $84.5 \%$ \\
\hline$>=10$ & 136 & $12.5 \%$ \\
\hline Unknown & 32 & $2.9 \%$ \\
\hline \multicolumn{3}{|l|}{ ESR 30min } \\
\hline$<20$ & 178 & $16.4 \%$ \\
\hline
\end{tabular}




\begin{tabular}{|c|c|c|}
\hline$>=20$ & 290 & $26.7 \%$ \\
\hline Unknown & 619 & $56.9 \%$ \\
\hline \multicolumn{3}{|c|}{ Procalcitonin } \\
\hline$<=0.05$ & 594 & $54.6 \%$ \\
\hline$>0.05$ & 221 & $20.3 \%$ \\
\hline Unknown & 272 & $25.0 \%$ \\
\hline \multicolumn{3}{|l|}{ D-Dimer } \\
\hline$<0.5$ & 510 & $46.9 \%$ \\
\hline$>=0.5$ & 265 & $24.4 \%$ \\
\hline Unknown & 312 & $28.7 \%$ \\
\hline \multicolumn{3}{|l|}{ BUN } \\
\hline$<=6.5$ & 859 & $79.0 \%$ \\
\hline$>6.5$ & 162 & $14.9 \%$ \\
\hline Unknown & 66 & $6.1 \%$ \\
\hline \multicolumn{3}{|l|}{ Creatinine } \\
\hline$<90$ & 917 & $84.4 \%$ \\
\hline$>=90$ & 104 & $9.6 \%$ \\
\hline Unknown & 66 & $6.1 \%$ \\
\hline \multicolumn{3}{|c|}{ Acсu-Tell Troponin } \\
\hline$<15.6$ & 593 & $54.6 \%$ \\
\hline$>=15.6$ & 66 & $6.1 \%$ \\
\hline Unknown & 428 & $39.4 \%$ \\
\hline \multicolumn{3}{|l|}{$I L-6$} \\
\hline$<10$ & 555 & $51.1 \%$ \\
\hline$>=10$ & 76 & $7.0 \%$ \\
\hline Unknown & 456 & $42.0 \%$ \\
\hline \multicolumn{3}{|l|}{$\operatorname{Ig} G$} \\
\hline Positive & 887 & $81.6 \%$ \\
\hline Negative & 120 & $11.0 \%$ \\
\hline Unknown & 80 & $7.4 \%$ \\
\hline \multicolumn{3}{|l|}{$\operatorname{Ig} M$} \\
\hline Positive & 797 & $73.3 \%$ \\
\hline Negative & 260 & $23.9 \%$ \\
\hline Unknown & 30 & $2.8 \%$ \\
\hline \multicolumn{3}{|c|}{ Imaging features } \\
\hline \multicolumn{3}{|c|}{ Consolidation } \\
\hline Yes & 525 & $48.3 \%$ \\
\hline No & 551 & $50.7 \%$ \\
\hline Unknown & 11 & $1.0 \%$ \\
\hline \multicolumn{3}{|c|}{ Ground-glass opacity } \\
\hline Yes & 730 & $67.2 \%$ \\
\hline No & 346 & $31.8 \%$ \\
\hline Unknown & 11 & $1.0 \%$ \\
\hline \multicolumn{3}{|c|}{ Bilateral pulmonary infiltration } \\
\hline Yes & 874 & $80.4 \%$ \\
\hline No & 202 & $18.6 \%$ \\
\hline Unknown & 11 & $1.0 \%$ \\
\hline
\end{tabular}

